\title{
Volunteerism as an alternative early warning system in supporting election supervision
}

\author{
Volunterisme sebagai alternatif sistem deteksi dini untuk mendukung \\ pengawasan Pemilu
}

\author{
Caroline Paskarina
}

Department of Political Sciences, Faculty of Social and Political Sciences, Universitas Padjadjaran Address: Jalan Raya Bandung-Sumedang Km. 21 Jatinangor, West Java 45363

E-mail: caroline.paskarina@unpad.ac.id

\begin{abstract}
The quality of an election can be measured by the number of violations that can be solved to ensure the legitimisation of the election results. Violations in elections are still a problem since the amount tends to increase, which needs a long period of time to be solved. The enforcement of the regulations, such as the role of Bawaslu, is limited because it only serves as a 'postman' who forwards the violation cases to another law enforcement institution. The shifting of electoral supervision towards a more participatory approach has become an opportunity to develop an electoral supervision model that involves the community, especially in the prevention phase. This article describes the emergence of the idea of volunteerism in the context of the election, particularly in the election's implementation monitoring and supporting the functions of Bawaslu. The article uses qualitative methods to analyse the various regulations in relation to monitoring and supervising the election, as well as various referral sources that contain voluntary practice information. The result of the study shows that an early detection system is an alternative method that can be developed, considering the voluntary spirit which is currently undergone an improvement. Therefore, it is necessary to build an early system in the prevention phase by conducting supervision on the implementation of the overall stages of the election and building public awareness to guard the integrity of the election results.
\end{abstract}

Keywords: volunteerism; participatory supervision; early warning system

\begin{abstract}
Abstrak
Kualitas penyelenggaraan pemilihan umum, salah satunya diukur dari jumlah pelanggaran yang dapat ditangani untuk menjamin legitimasi hasil pemilu. Pelanggaran dalam pemilu hingga sekarang masih menjadi persoalan karena jumlahnya yang cenderung meningkat dan penanganannya yang memerlukan waktu. Persoalan dalam pengawasan pemilu adalah penegakan hukum karena Bawaslu seolah hanya menjadi seperti 'tukang pos'yang meneruskan kasus-kasus pelanggaran pemilu kepada lembaga lain. Paradigma pengawasan pemilu mengalami pergeseran ke arah yang lebih partisipatif, sehingga menjadi peluang untuk mengembangkan model pengawasan pemilu dengan melibatkan masyarakat, khususnya pada tahap pencegahan. Tulisan ini menguraikan kemunculan gagasan volunterisme dalam konteks pemilu, khususnya dalam pelaksanaan pemantauan pemilu untuk mendukung pelaksanaan fungsi Bawaslu. Metode kualitatif melalui studi literatur dipakai untuk menganalisis berbagai regulasi yang mengatur tentang pengawasan dan pemantauan pemilu, serta terhadap berbagai sumber rujukan yang memuat dokumentasi praktik kerelawanan dalam pengawasan pemilu. Hasil kajian menemukan bahwa sistem deteksi dini pengawasan berbasis volunterisme merupakan alternatif yang dapat dikembangkan mengingat semangat kerelawanan yang saat ini tengah mengalami peningkatan Untuk itu, perlu dibangun sistem deteksi dini yang berfokus pada dimensi pencegahan dengan melakukan pemantauan terhadap penyelenggaraan seluruh tahapan pemilu serta membangun kesadaran masyarakat untuk mengawal integritas hasil pemilu.
\end{abstract}

Kata kunci: volunterisme; pengawasan partisipatif; sistem deteksi dini

\section{Introduction}

The general election is one of the indicators of the fulfilment of the people's sovereignty. However, its implementation still faces a number of obstacles, particularly in handling the violations that occur in various stages of the election. The increasing number of violations and the limited number of election 
supervisors up to the grass root level is suspected to be the cause of the lack of supervision by the Bawaslu (Badan Pengawasan Pemilu). There have been some efforts to strengthen the authority of Bawaslu through the regulation Act no. 15 the year 2011 about Election Organisers, which gives Bawaslu status at the national and provincial level, and increases the number of supervisors at the village level (Field Supervisor or PPL), up to five persons per village. There have already been some efforts to strengthen the monitoring performance as contained in Act no. 7 of the year 2017 on General Election, which states that Bawaslu is authorized to prevent and prosecute violations of elections and disputes of the electoral process. This provision changed Act no. 15 of the year 2011, in which the authority of Bawaslu is only to conduct prevention and prosecution for violation of election. However, the number of violations that occur in the election is still increasing. This is a problem since that if the supervision is expected to reduce the number of fraud occurrences and disputes in the process of the election, then it means that the expectations are not being realised.

The problems to do with the effectiveness of election surveillance can be analysed from different perspectives. From the regulation side, Santoso (2011) argued that the design of electoral regulations needs to be more directed in order to protect the election process from deception. Law enforcement is an effort to ensure election integrity. Because of that, Santoso (2011) recommends that within the legal framework regarding the law enforcement of electoral offenses, there are several things to consider. The first is that the criminal act of the election shall include prohibition misconduct, which could directly or indirectly affect the outcome of the election. Second, the criminal act of the election shall include all actions that threaten the election process. Therefore, the subjects of election crime should not be limited to candidates only. In addition, the regulatory targets should also include community members, voters, candidates, and political parties, organisers, staff, government officials, security staff, law enforcers, and even foreign communities. Third, the regulations that are related to the election crimes must adequately be protected at every stage of the election. The reason for this is because at each stage, any crime against the basic rights of the community, either directly or indirectly, could affect the election results. This is because all of the election stages are crucial in the election process. The regulations relating to election offenses should not only focus on a particular stage (such as the campaign stage) but also on the fraud that occurs in voter registration, supported by certain parties or candidates that have not yet registered. The same thing also happens in vote calculations.

From the institutional side, the effectiveness of supervision cannot be separated from the role of the election supervisory body. The role of Bawaslu as an intermediary institution in distributing the reports of offenses is considered to be the cause of the slow settlement of disputes. Because of that, Harun (2015) offers the idea of transforming the role of Bawaslu from a regulatory agency into a judicial institution for election violation cases. This offer is based on the assumption that what Bawaslu really needs to do is optimise its role in resolving the election disputes based on UU no. 82012 about the General Election of Members of $D P R, D P D$, and DPRD. Through this authority, Bawaslu no longer seems to be a 'postman' that channels various reports of violations to other agencies, but it has the authority to decide on the electoral violations itself. Unlike the two previous opinions which emphasise the handling of election violations on the law enforcement aspects, this paper focuses on the prevention aspects of election offenses. Handling the protracted cases of violations can cause high social costs as they often lead to conflict between supporters and riots, which could bring harm to society. This condition generates public apathy towards the election. It is why supervision also needs to be directed to minimise the possibility of election violations, especially to create a conducive situation when organising a safe election.

The opportunity for the optimisation of supervision focused on the prevention aspects obtained on a legal basis came in Act no. 8 year 2012 about the General Election of Members of DPR, DPD, and DPRD, where the supervisory functions undertaken by Bawaslu and the Regency/Municipal Panwaslu should ensure that the election is running in accordance with the terms and conditions that have been agreed to in order to prevent the election offenses. The problem then is whether, with the number of supervisors owned by Bawaslu and the Regency/Municipal Panwaslu, this function will be able to run effectively. With the wide area coverage of the election, it is certain that the prevention 
function will be difficult to do without involving other components of society. The data indicates that the reports of election offenses coming from the community turned out to be more than those from the election supervisory officers. Quantitatively, the reports of violations submitted by the communities and participants of the 2014 Election increased from 2013 (at the registration stage for the political parties who participated in the election and updated the voter data). In 2013, there were 1,001 reports to Bawaslu and later in 2014, this rose to 2,722 reports (Bawaslu 2014). This amount is directly proportional to the findings of violations by the election supervisory officers (Bawaslu and Regency/ Municipal Panwaslu) in 2014, with a total of 5,731 findings (Bawaslu 2014). The high number of violations indicates that there is still a big problem in ensuring the legitimacy of the election results, especially in guarding vote quality provided by the voters.

On the other hand, the increase in the number of violation reports that were submitted by the public is also an important indication of the increase of public awareness about participating in overseeing the election. Public participation in the general elections is associated with involvement in campaigning, voting, and election monitoring. Community involvement in electoral supervision is a relatively new thing since the role of election supervision becomes the authority of formal institutions that are assigned to prevent and prosecute various violations, to resolve election disputes, and to receive and forward reports of election violations.

This role is different from election monitoring, in which the scope only observes the election process and takes action when there are procedures or electoral rules being violated. Since the 1999 general election, it has been possible for the public to contribute to election monitoring. As democracy grows, a wider public participation space is needed to control the rights of the vote through the public's involvement in electoral supervision. By involving the community in participating in election supervision, it could complement the functions and duties of Bawaslu in controlling the implementation of honest and fair elections.

Within the framework of participatory supervision, Bawaslu then initiated the "One Million Volunteer Election Supervisors Movement" to participate in supervising the Legislative Election in 2014. By recruiting university students from various institutions in Indonesia, the movement was intended as a platform for active students to participate in the framework preventing election violations. The student's active role included the following activities: ensuring that they and others were registered on the Permanent Voter List (DPT); ensuring that the candidates for DPR, DPD, and $D P R D$ members were eligible; ensuring that the organising process was in accordance with the laws and regulations and inviting the public to bring their voting rights to the ballot. In addition to these forms of supervision, the students also reported to the election supervisor if there was any potential or alleged election violation in order for it to be followed up by the election supervisor, through the mechanism that was arranged in Bawaslu's regulations about findings and violations.

This movement is a breakthrough step that needs to be appreciated, as it is able to include the community to prevent election violations. However, there are still problems in terms of the sustainability of the movement and its synergy with the supervision performance conducted by Bawaslu and the Regency/ Municipal Panwaslu. In fact, the potential of volunteerism is huge and can be managed in order to support the performance of Bawaslu and the Regency/Municipal Panwaslu. The success of Bawaslu in mobilising a million election supervisory volunteers from the student body became a real indicator of the potential of the volunteerism spirit. In order for this potential to be managed optimally, there are at least three aspects that need to be prepared by Bawaslu, which are the regulation of the scope of the duties done by the election supervisory volunteers in relation to violation prevention; the capacity building that requires training volunteers and to ensure the sustainability of the movement, especially in relation to guarding the election of the regional heads. To discuss these three aspects, this paper outlines the concepts that are related to volunteerism and electoral supervision. Then it goes on to further explain the scope, capacity, and sustainability of volunteerism that can be developed to strengthen the prevention aspect of the supervisory election organiser, so that volunteerism can serve as a support for the early detection systems of election violations.

\section{Research Method}


This study was conducted using qualitative methods, with the purpose that the results of the research could reveal the chronological flow of the sequence of the events involved, why it happened and what is the consequence of the events (Tracy 2013). The analysis of the chronology and consequences that had arisen from the event was conducted by interpreting various sources of data (reports, articles, and other literature, including the primary data) that shapes reality (Tracy 2013). The secondary data in the form of existing literature was obtained through various regulations, including the arranging of supervision and the monitoring of elections, as well as using the various resources that contain the documentation of volunteer practices in relation to electoral supervision in Indonesia or in other countries.

The secondary data collection through the literature review was directed to obtain information on 1) the scope of the duties of the electoral supervisory volunteers to prevent electoral offenses; 2) capacity building is needed to train the volunteers, and 3) the sustainability of the movement, particularly to assist in supervising the election of regional heads. The data was then processed using qualitative analysis techniques, by interpreting several facts and information in order to obtain an understanding of the studied phenomenon (Bungin 2003).

\section{Results and Discussion}

\section{Volunteerism in general election}

Volunteerism is a phenomenon that originally developed in the social realm in the form of social work (non-profit), which corresponds to altruistic behaviour (Haski-Leventhal 2009). The social work is done based on humankind, so it is often seen of as a neutral form of political interest, in the sense of gaining power or a government position.

In the next stage of development, the study of volunteerism began to focus on a number of dimensions within volunteer activity (Hustinx, Cnaan, \& Handy 2010), such as the motivational dimension within someone who is willing to do voluntary action (Omoto, Snyder, \& Hackett 2010, Wilhelm \& Bekkers 2010, Wilson 2012), volunteerism dynamics (Haski-Leventhal \& Bargal 2008), the impact that results from volunteerism (Theiss-Morse \& Hibbing 2005, Wollebaek \& Selle 2012), and the duration of involvement in volunteerism (Chacón, Vecina, \& Dávila, 2007). These three dimensions have become mainstream within the scope of volunteerism studies.

The case studies found that motivation is based on the personality of the individuals who have a caring personality towards others, and have empathy and solidarity with other people (Wilhelm \& Bekkers 2010). This personal motivation also relates to the values of morality and spirituality within a person. Aside from this coming from their character, their participation in voluntary activities is also driven by the surrounding environmental factors. For example, they are actively involved in certain social environments (Lee \& Brudney 2012). These internal and external factors are essentially inseparable, especially in the midst of current trends, where voluntary activity becomes part of activism in social and political movements (Eliasoph 2013, Suaedy 2014).

As a form of social movement, there are various characters of voluntary activity. For instance, they are directed at encouraging systemic and long-term changes to address the problems faced by communities. On the other hand, there also other voluntary activities that are not systemic, such as that directed at assisting individuals or communities to solve their problems (Snyder \& Omoto 2008). Although there are variations in volunteer activity, the essence remains the same, which is that the voluntary movement is served when a social action is carried out for the benefit of others, either for individuals, the movement itself, the communities involved and even other societies.

Snyder \& Omoto (2008) describe six criteria that distinguish volunteerism from other social activities: first, volunteerism must be based on volunteerism, without coercion from any party. Although the volunteers who are involved may receive rewards for the activities that they do, their involvement is still voluntary. The second criterion is that volunteerism aims to provide services to others or influence policies, not to provide emergency assistance. The third is that the action of volunteerism must be done over a period of time, not just as a one-time activity. The fourth is that the decision to 
follow voluntary activities is entirely determined by the motivation of a person that is not for a reward or to avoid punishment. Fifth, is that what the volunteers do must also voluntarily be accepted by the target, and where there is no coercion for others to accept the voluntary action. The sixth criterion is that volunteerism is generally done through organisations, both formal and informal. These six criteria suggest that not all actions are social and can be categorised as a form of volunteerism.

In fact, voluntary-based work practices cannot be separated from political activity, especially if it is intended to make a change to wider public life (Eliasoph 2013). This condition causes volunteerism and political activity to be included in the civic engagement category, which is defined as activities carried out by individuals or groups for the sake of public interest (Eliasoph 2013, Ayala 2000). The difference lies in the purpose that needs to be achieved and the way to achieve it. Usually, volunteer activity is conducted to solve social problems directly, whereas political activity is generally done through indirect ways to influence policy.

Volunteerism can serve as a means to renew the values of citizenship, able to sustain people's lives, which in turn can contribute to the realisation of collective capacity as a precondition for the work of democracy (Suaedy 2014). The concept of volunteerism used in this article refers to the collective desire to create systemic changes through established procedures, but with the realisation that it cannot be initiated by the dominant actors or institutions. As a part of citizen engagement, voluntary practice is based on a specific motive, such as an awareness of people's responsibilities as a citizen (Haddad 2007). This awareness places volunteerism as an important part of supporting the work of democracy (Putnam 2000).

Volunteerism that ensouls public participation becomes a pillar of democratisation as a concept of participatory democracy (Ibrahim 2017). Therefore, the development of volunteerism in political dynamics in Indonesia today, including the holding of elections, is also an indication of the strengthening of citizen participation in the electoral political field (Suaedy 2014). This phenomenon is crucial to the growth of democracy in Indonesia because for more than three decades, the pattern of public participation in the elections has tended to be in the form of mobilisation to vote. The public is not an autonomous subject allowed to determine its choice, let alone engaged in a wider scale of elections that become the domain of state authority. On the other hand, the presence of volunteers in the dynamics of the elections also changes its practice, which is often identical with money politics, causing the election to be an expensive 'party of democracy'.

The emergence of volunteerism in the elections also marks a shift in relations between society and political parties (Pontoh 2014). In the past, in electoral politics coloured by the nuances of authoritarianism, society is positioned as a mass of voters that can be mobilised by political parties. After the reforms took place, the marginalisation of society still continued to be done through various money-based political strategies to 'buy people's votes'. The relationship of power that makes the public passive creates an apathetic attitude towards electoral politics which they regard only as a formal mechanism of power changes. In the midst of weakening the trust in political parties and vice versa, the strengthening of political figures and the party structure as an instrument to gather the votes began to be abandoned by the candidates. On the contrary, rapid technological advancement provides wider spaces for public participation to channel their freedom and aspirations. The public will find an alternative channel outside of the political parties to express their aspirations through various social media. This condition creates a new style of volunteerism not only due to a personal concern on a particular issue and not only for a particular community, but through the use of a wider network through various social media.

In the 2014 election, especially in the presidential election, the voluntary phenomena emerged massively in the form of volunteer mobilisation as part of the presidential campaign team. One that is quite phenomenal was the Jokowi volunteers who came from various backgrounds. Savirani conducting mapping (2015) which showed that Jokowi volunteers were divided into three categories: first, the volunteers who were formerly pro-democracy activists in the 1990s who were critical during 
the New Order regime and the Suharto government. The second category was made up of volunteers who were also activists from various organisations or non-government organisations, which carry out work against the issues of corruption as a defender of peasant rights, supporting labourers and indigenous peoples. The third category was made up of volunteers from the arts and creative sector actors. The third category largely lacks political experience compared to the first and second category. It has been proven that the spread of political participation is capable of reaching out to non-political groups of people. Nonetheless, because the volunteers in the third category were public figures, it was easier to attract sympathy and public support for the movement. Their popularity became one of the important assets that made the voluntary movement successfully mobilise public support for the Jokowi campaign (Savirani 2015).

Volunteerism that developed in the context of Indonesian elections, especially during the legislative and presidential elections in 2014, emerged as a reaction to the wider participation space, the growth of public awareness, and the weakening of political parties functioning as a channel for public aspiration. Volunteerism is an alternative channel that is selected by the public who have the political awareness to encourage changes when the available formal channels are considered to be inadequate. Therefore, in this perspective, volunteerism in elections has transformed into political activity that not only to empowers the public, but also concretely takes advocacy steps to supervise the holding of elections, such as establishing various election monitoring groups as well as using technology, such as www.kawalpemilu.org, www.rumahpemilu.org., and so on.

The public willingness to participate in this volunteerism movement becomes a potential power in relations management between the state and society. Public assessment of the state will determine the type of civil organisation formed, whereas the practices of various social and government institutions will determine the level of community participation (Haddad 2007). This means that the development of volunteerism in elections can be used to restore public confidence in the electoral process.

Since the 1999 elections, the expansion of public participation through volunteerism has been accommodated through the presence of various election monitoring institutions. The election observers work only to monitor the organisation. On the other hand, the election supervisors have the duty and authority to resolve the election violations and disputes. Thus, the monitoring work is a form of public participation that must be reported and forwarded to the election supervisors in order to be followed up (Santoso \& Supriyanto 2004). Supervision is part of the controlling function of the election organiser that has been institutionalised, and who receives public reports and follows up on those reports (Junaidi 2013). The existence of an election monitor is to serve as a partner of the election supervisors, in which their role in monitoring is to fill in the limitations of the number of supervisors as well as to monitor the election supervisory activities at various levels, carrying out their duties with authority to improve the performance of the election supervisory institutions (Santoso \& Supriyanto 2004). The difference between monitoring and supervision in election holding provides the basis for determining the oversight scope of participation.

In 2014 post-election, the space of participation increasingly expanded and became substantive with the presence of volunteers involved in political education activities, political campaigns and electoral supervision. A participatory oversight concept was developed by involving volunteers who played the role of election supervisors. Sardini (2011) mentioned that there are five roles that can be performed by election observers, which are: to give legitimacy to the election process; to increase respect and trust in relation to human rights, especially civil and political rights; to increase confidence in the election process; to build trust in democracy and to support efforts to resolve local conflict peacefully. Referring to the above arguments, the participatory oversight can be designed to adopt these five roles. To play a more substantive role, the concept of volunteerism needs to be developed in a more strategic direction. Volunteers are not only recruited for tactical, sporadic or temporary work, but they need to train and develop their capacity in order to be able to prevent election offenses by conducting political education and monitoring activities.

The early detection system of electoral supervision by involving volunteers is focused on the prevention of violations so that the volunteer capacity can be directed to carry out its function as 
optimally as possible. In this early detection framework, volunteer supervision includes several activities to ensure the integrity of each stage of the election process by collecting the data and information and inventorying cases which are related to the elections done by community groups or independent and non-partisans (Thubany 2010). In addition, in order to ensure the implementation of people's political rights, early detection systems are developed and should be directed to facilitate the critical awareness of the community to guard the democratic elections (Junaidi 2013).

\section{The scope of involvement of volunteers in electoral supervision}

Bawaslu regulation number 13/2012 in Article 22 about the Procedures for General Election Supervision specifically regulates public participation in election oversights. The regulations state that community participation in electoral supervision can be done in four ways, which are: monitoring, the submission of preliminary reports and/or preliminary information on the findings of alleged violations, studying the case, campaign monitoring and other forms that do not violate the legislation. This regulation also provides a guide for the Bawaslu in order to increase community participation in electoral supervision, with the following steps: actively encouraging the role of the community to oversee the election; providing adequate information, and the facilities to facilitate the access to information about election control and preparing easy facilities for the community to deliver information, compliance and/or reports of election violations.

In 2009, Bawaslu began implementing a participatory oversight by involving Rector Forum as a partner. However, implementation through the concept of volunteering was initiated in 2014 through the "Million Volunteer Movement". The term "million volunteers" was used to indicate the large number of people who were involved, and the extent of the movement (Minan 2014). Therefore, it is hoped that the societies engaged will be more concerned about the importance of supervision in ensuring the quality of the election. The conceptualisation of the "Million Volunteer Movement" comes from a civil society that is incorporated in various non-governmental organisations, such as the Independent Election Monitoring Committee (KIPP), JPPR, IPC, ICW, Formappi, SSS, Tepi and others (Bawaslu 2014).

Although the movement is expected to mobilise as many citizens as possible to engage in the election oversight, in this movement, the people that can be the volunteers are Indonesian citizens who are registered as voters (minimum age of 17 on April 9, 2014, on the day of voting) including (Senior High School/Vocational High School/Madrasah Aliyah) students that are recruited by the committee of election supervisors or people who are registered and meet the requirements. Members of community organisations and general society can also become volunteers in this movement by verifying their independence. They will conduct surveillance in their residential areas in some stages of the General Election based on the assignment of the National Working Group (Pokjanas) and coordination with the committee of election supervisors (Minan 2014).

The volunteers who joined this movement performed a number of roles in the three stages of the elections: campaign monitoring, quiet period monitoring and the monitoring of voting and vote counting (Minan 2014). This is compared to the scope of electoral supervision that covers the upstream, middle and downstream. The role of volunteers in the "Million Million Movement" is limited to the central scope (when the election takes place).

This supervision is only one process, where there will also be a continuation process of reporting, action and sanction decisions, which should always be watched by the public. So far, community participation tends to focus on the election monitoring stage. However, in the case of the report violation process and the monitoring of the reporting process, it is still lacking. To fill that deficiency, it is necessary to develop a system of early detection surveillance that is based on volunteerism. It is focused on covering two dimensions, which are 1) to oversee the integrity of the election implementation and 2) to raise public awareness about political rights in the election. In the first dimension, volunteer involvement is directed towards receiving, collecting, and submitting complaints and reports of election violations. In the second dimension, the involvement of volunteers also includes the delivery of political education to increase public participation, as well as to provide information about the strategic value of elections for governmental improvement. 
Table 1.

The scope of election supervision

\begin{tabular}{|c|c|c|c|}
\hline $\begin{array}{l}\text { Dimen- } \\
\text { sions }\end{array}$ & $\begin{array}{c}\text { Upstream } \\
\text { (Prevention) }\end{array}$ & Middle & Downstream \\
\hline Focus & $\begin{array}{l}\text { Social and political facts } \\
\text { that surround the election, } \\
\text { which includes: } \\
\text { a. conditions of political } \\
\text { infrastructure and political } \\
\text { superstructure in the } \\
\text { political system. } \\
\text { b. political culture including } \\
\text { behaviour and political } \\
\text { communication. }\end{array}$ & $\begin{array}{c}\text { Any potential } \\
\text { violations }\end{array}$ & $\begin{array}{l}\text { Any matters that } \\
\text { are related to any } \\
\text { violation indicator } \\
\text { that occurred }\end{array}$ \\
\hline Activities & $\begin{array}{c}\text { Socialisation; public } \\
\text { campaigns, research and } \\
\text { surveys, and partnerships } \\
\text { for active community } \\
\text { engagement }\end{array}$ & $\begin{array}{l}\text { Coordination as an effort to } \\
\text { synchronise the perceptions } \\
\text { between election organisers } \\
\text { and the public; technical } \\
\text { guidance and consolidation } \\
\text { meetings with the committee } \\
\text { of election supervisors; study } \\
\text { and analysis of the case; } \\
\text { an early warning system } \\
\text { through an official letter to } \\
\text { the election organisers and } \\
\text { election participants. }\end{array}$ & $\begin{array}{c}\text { Inherent } \\
\text { supervision as } \\
\text { well as audit and } \\
\text { verification }\end{array}$ \\
\hline
\end{tabular}

a. Societal organisations and religious organisations, which are representative and have a major influence

Stakeon society

holders

b. Colleges and educational institutions

c. Survey agencies and research institutes
a. Youth organisations and
Civil Society Organisations
b. Election participants and election organisers
c. State Commission/State Institutions that are involved
a. Election monitors
b. State Commission or State institutions that involved with the potential prevention of violations

\begin{tabular}{|c|c|c|c|}
\hline Output & $\begin{array}{l}\text { Public awareness; mapping } \\
\text { the potential conflicts and } \\
\text { mapping the vulnerable } \\
\text { locus of violations }\end{array}$ & $\begin{array}{l}\text { Minimisation of potential } \\
\text { violations and understanding } \\
\text { in electoral supervision by the } \\
\text { community }\end{array}$ & $\begin{array}{c}\text { Supervision } \\
\text { documents in the } \\
\text { form of a surveillance } \\
\text { review report as a } \\
\text { recommendation } \\
\text { for action, as well as } \\
\text { preliminary evidence } \\
\text { as an input action on } \\
\text { the violation }\end{array}$ \\
\hline
\end{tabular}

\section{Source: Election Supervision Report (Bawaslu 2014)}

To be able to carry out both roles, the recruitment of volunteers is done from various social circles using a tiered development pattern. The recruitment aims to develop the volunteers themselves, not just to do the voluntary activity once but on a sustainable basis. After the volunteers are recruited, then the coaching is conducted in a tiered pattern by making the volunteers understand their role and contributions which are expected to improve the quality of the election. These volunteers are formed into democratic agents who will perform both roles like that in the scope of the early detection systems of electoral supervision. The performance of the volunteers continues to be monitored by trainers throughout their tenure, including 
before and after the election stages are completed. The mechanism is implemented so that the institutionalising process of the principles and objectives in electoral supervision can take place on an ongoing basis. Broader engagement can also cover student recruitment, election activists, and other civil members of society. This makes the volunteer capable of expanding their influence in terms of territorial and social stratification. The efforts to build public awareness about the importance of elections for democratic growth are often difficult to reach marginalised groups of people. As a result, the volunteers can be used to support the task of KPU and Bawaslu in providing political education.

To support the role of agent of political education, the performance of the volunteers needs to be supported by the existence of a data centre and education in election monitoring that can be managed by Bawaslu. This institution will serve as a knowledge reproduction centre that makes the supervision not merely a technical activity, but also part of democratic learning. The identification of developments in the types of violations, modes, actors, and the ways of handling the problem converted into a source of knowledge can be developed to formulate a model of monitoring that is relevant and actual.

\section{Volunteers capacity building}

Volunteer capacity building can be conducted through training programs which are held between the election periods by involving various parties who have experience, such as the teams that do election monitoring, people from universities, police institutions and local community groups in order to enrich their knowledge. Through this training, the coordination with other institutions that are involved in organising the elections could be strengthened, therefore building mutual trust and cooperation between supervisory staff and volunteer personnel.

The volunteer figure who is expected to build an early detection system that could effectively work is the one who has the ability to analyse the situation as well as to perform political empowerment actions. At the beginning of recruitment, a basic mapping of volunteer capacities should be undertaken. As a result, the training model can be structured more specifically according to the basic capacity. The training materials and methods will vary according to the group of trained volunteers. Despite possibilities in the variation of materials and methods, there is still a standardised level of competency. Basic competencies, for example, cover knowledge of electoral law, supervisory principles and monitoring techniques, as well as mechanisms in reporting and handling violations. In the next level of training, this competency can be improved by adding in training materials on election management, logistics, and operational monitoring plans.

Besides cognitive training, the capacity-building action for volunteers is also conducted to provide training in relation to violations handling and advisory techniques which makes the people who see the violations willing to report them and to become witnesses in those cases. Early detection systems will be effective to minimise the number of violations since this system will be able to prevent violations. This requires support from society. Therefore, the action capacity that needs to be developed among volunteers is required to be integrated with the political education available for voters. Education not only provides information about the voting mechanism, but it informs of the importance of community participation to guard the votes which later on could impact on any changes. The problem is not in determining who the candidates are or what party is chosen, but every choice will have an impact on government public policy that runs between the two election periods.

In addition to the above two capacities that are related to the scope of the early detection surveillance system, volunteers also need to be trained in order to have managerial skills that are linked to technical implementation. In performing their duties, each volunteer will meet, communicate, coordinate, and cooperate with other stakeholders. Therefore, it is important for the volunteers to know how to carry out these tasks effectively and efficiently.

\section{Volunteerism sustainability}

The sustainability of early detection surveillance systems is primarily determined by the availability of knowledge systems and volunteers who become the driving force of the system. The development 
of the volunteer capacity is done together with institutional capacity building, and both the structure and function should be carried out to support the prevention duties conducted by Bawaslu. Bawaslu needs to define its violation prevention targets, through mapping the violations that often occur and that can be categorised as serious violations. This can be done if Bawaslu often conducts various research studies on law enforcement processes. This starts from the weaknesses of the regulations, the form of the violations and the modes up to the actors who are involved. This research study is important to map the existing prevention strategies appropriately and precisely. The results from this will be used as material to develop strategies and forms of prevention, and to improve the supervision and capacity building of the volunteers.

Similar to the volunteer capacities which includes the situational analysis capacity and action capacity, the continuation of early detection systems are built on the foundation of knowledge - the actionreflection cycle. The initial phase of volunteer recruitment and each level of training is intended to form volunteers who have the capacity to correspond to the needs of the system. At this stage, the knowledge and skills given to the volunteers are a basis for when the volunteers perform their duties. As a strategic volunteer, a volunteer figure who is capable of ensuring the sustainability of an early detection system is a volunteer who not only knows and understands the knowledge and basic skills that have been provided, but they have to believe that their knowledge and skills that they have is able to bring improvements to the elections.

In the next stage, when the knowledge and skills are practised directly, the volunteers become democratic agents who are not only supervised, but also play a role in empowering the community in order to have an awareness of supervisory participation, at least to conduct electoral supervision in their native surroundings. Through supervisory action, the volunteers are transferring and disseminating their knowledge and skills to the community and thus forming new knots in supervision at the grass root level. These knots may well become a source for the next round of volunteer recruitment, but far more importantly, the existence of these knots becomes an instrument to form a society with an awareness of its political rights. Bawaslu should encourage the people to continue monitoring in order to maintain the monitoring activity effectively. Hence, any report of violations should be taken seriously. Bawaslu not only receives reports, but also helps to facilitate people's complaints to meet both formal and material requirements so that the violation reports can be taken into account.

The reflection stage becomes a feedback stage to improve knowledge, the training model, and the volunteer capacity. In the period between before and after the next period of the election, reflection on the activities that have been done is needed to rearrange the knowledge system, so that the data available and information centre always stays updated. The various development models, instruments and monitoring techniques, as well as volunteer development, also takes place at this stage. Accordingly, the sustainability of early detection systems is also supported by the reproduction of knowledge that allows for the continuation of the action without the limitation of the election period.

\section{Conclusion}

The concept of monitoring participation that was developed by Bawaslu has great potential to support supervisory performance effectively, especially in terms of encouraging and raising public awareness and for the public to participate in overseeing the election. According to many participatory surveillance models, the early detection system of volunteer-based supervision is an alternative that can be developed since voluntary power is currently increasing.

Early detection monitoring systems based on volunteerism focuses on violation prevention, which includes two spheres of activities, namely controlling the implementation of all election stages and political education for the community to build public participation in the context of guarding the election. This scope allows for early detection systems to continue to work beyond the election period, in order to integrate the role of election monitoring that is generally carried out by various community components with electoral supervision into the realm of Bawaslu authority. Volunteer recruitment should be always open and the capacity 
building conducted at various levels to help to form a volunteer figure who has the capacity to analyse the situation and is capable of political empowerment actions. The development of the knowledge centre becomes a supporting instrument to ensure the sustainability of the reproduction knowledge systems which are necessary for the optimisation of the supervisory performance. The sustainability of the voluntary-based early detection monitoring system is also built through the synergy between knowledge-action-reflection. Therefore not only is the volunteer capacity being developed, but also the reproduction of knowledge is necessary to ensure the institutionalisation of democracy through electoral supervision.

\section{References}

Ayala LJ (2000) Trained for democracy: The differing effects of voluntary and involuntary organizations on political participation. Political Research Quarterly, 53 (1):99-115.

Bawaslu (2014) Laporan hasil pengawasan Pemilu tahun 2014. https://www.Bawaslu.go.id/hasil_pe ngawasan/235b26e3fae9c00e9445a8d91959a5bf/hasil_pengawasan_pemilu/1599.

Bungin B (2003) Analisis Data Penelitian Kualitatif: Pemahaman Filosofis dan Metodologis ke Arah Penguasaan Model Aplikasi. Jakarta: RajaGrafindo Persada.

Chacón F, Vecina ML, dan Dávila MC (2007) The three-stage model of volunteers' duration of service. Social Behavior and Personality: An international journal, 35 (5):627-42.

Eliasoph N (2013) The Politics of Volunteering. Cambridge: Polity Press.

Haddad MA (2007) Politics and Volunteering in Japan: A Global Perspective. Cambridge: Cambridge University Press.

Harun R (2015) Transformasi pengawas Pemilu: Dari pengawas ke pengadil. Jurnal Pemilu dan Demokrasi, 7:91-100.

Haski-Leventhal D (2009) Altruism and Volunteerism: The perceptions of altruism in four disciplines and their impact on the study of volunteerism. Journal for the Theory of Social Behaviour, 39 (3):271-99.

Haski-Leventhal D \& Bargal D (2008) The volunteer stages and transitions model: Organizational socialization of volunteers. Human Relations, 61 (1):67-102.

Hustinx L, Cnaan RA, \& Handy F (2010) Navigating theories of volunteering: A hybrid map for a complex phenomenon. Journal for the Theory of Social Behaviour, 40 (4):410-34.

Ibrahim (2017) Menakar kedalaman pengukuran demokrasi model Indeks Demokrasi Indonesia (IDI): Beberapa catatan substantif dari Kepulauan Bangka Belitung. Masyarakat, Kebudayaan dan Politik, 30 (2):133-149.

Junaidi V (2013) Pelibatan dan Partisipasi Masyarakat dalam Pengawasan Pemilu. Jakarta: Perkumpulan untuk Pemilu dan Demokrasi (Perludem) bekerjasama dengan The Asia Foundation (TAF).

Lee Y \& Brudney JL (2012) Participation in formal and informal volunteering implications for volunteer recruitment." Nonprofit Management \& Leadership, 23 (2):159-80.

Minan A (2014) Pengawasan partisipati Pemilu 2014 melalui Gerakan Sejuta Relawan. [Accessed 21 November 2017]. http://ahsanulminan.webs.com/Presentasi/Pengawasan\%20Partisipatif. pdf.

Omoto AM, Snyder M, \& Hackett JD (2010) Personality and motivational antecedents of activism and civic engagement. Journal of Personality, 78 (6):1703-34.

Pontoh CH (2014) Arah baru hubungan relawan dan negara. [Accessed 20 December 2015]. http:// indoprogress.com/2014/08/arah-baru-hubungan-relawan-dan-negara/.

Putnam RD (2000) Bowling Alone: The Collapse and Revival of AmericanCommunity. New York:Simon \& Schuster.

Santoso T (2011) Problem desain dan penanganan pelanggaran pidana pemilu. Jurnal Pemilu dan Demokrasi, 1:25-48. 
Santoso T \& Supriyanto D (2004) Mengawasi Pemilu Mengawal Demokrasi. Jakarta: Murai Kencana-PT Raja Gravindo Persada.

Sardini NH (2011) Restorasi Penyelenggaraan Pemilu di Indonesia. Yogyakarta: Fajar Media Press.

Savirani A (2015) Jokowi's supporters are to doubt the 'Indonesian Obama. [Accessed 20 November 2016].http://theconversation.com/jokowissupporters-are-starting-to-doubt-theindonesianobama-37843.

Snyder M \& Omoto AM (2008) Volunteerism: Social issues perspectives and social policy implications. Social Issues and Policy Review, 2 (1):1-36.

Suaedy A (2014) The role of volunteers and political participation in the 2012 jakarta gubernatorial election. Journal of Current Southeast Asian Affairs, 33 (1):111-38.

Theiss-Morse Edan Hibbing JR (2005) Citizenship and civic engagement. Annual Review of Political Science, 8 (1):227-49.

Thubany SH (2010) Bersama Masyarakat Mengawal Pemilu 2009. Jakarta: Yayasan TIFA dan JPPR.

Tracy SJ (2013) Qualitative Research Methods: Collecting Evidence, Crafting Analysis, Communicating Impact. United Kingdom: Wiley-Blackwell, A John Wiley \& Sons, Ltd., Publication.

Wilhelm MO \& Bekkers R (2010) Helping behavior, dispositional empathic concern, and the principle of care. Social Psychology Quarterly 73(1): 11-32.

Wilson J (2012) Volunteerism research: A review essay. Nonprofit and Voluntary Sector Quarterly, 41 (2):176-212.

Wollebaek D \& Selle P (2012) Does participation in voluntary associations contribute to social capital? The Impact of Intensity, Scope and Type. Non Profit and Voluntary Sector Quarterly, 31 (1):32-61. 